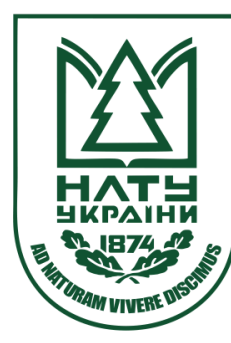

Науковий вісник НлтУ України

Scientific Bulletin of UNFU

ISSN 1994-7836 (print)

http://nv.nltu.edu.ua

https://doi.org/10.15421/40280408

Article received 03.04.2018 p.

Article accepted 26.04.2018 p.

ISSN 2519-2477 (online)

УДК 342.25:332

@ Correspondence author

K. P. Danylkiv

krisdanko@ukr.net

Н. М. Добош, Х. П. Данилків, П. А. Гориславець

Національний університет "Львівська політехніка", м. Львів, Україна

\title{
ФОРМУВАННЯ ДОХОДІВ ОБ'ЄДНАНИХ ТЕРИТОРІАЛЬНИХ ГРОМАД В УМОВАХ УДОСКОНАЛЕННЯ ПОДАТКОВОГО ЗАКОНОДАВСТВА
}

Досліджено вплив податків та відповідно податкової політики держави на формування доходів об'єднаних територіальних громад. В умовах бюджетної децентралізації зміни бюджетного та податкового законодавства призведуть до відповідних змін структури податкових надходжень та їх розмежування між бюджетами різних рівнів. Комплексна децентралізація передбачає широкомасштабний процес, у ході якого виділяють окремі елементи бюджетних і небюджетних джерел фінансових ресурсів та визначають особливості їх впливу на позитивний результат проведених реформ. Проаналізовано сучасну модель міжбюджетних відносин в Україні. Встановлено чинники формування доходів місцевих територіальних громад та оцінено вплив на їх соціально-економічний розвиток. Визначені можливості і загрози проведення децентралізаційної реформи не мають стати на заваді для iï реалізації. Надано практичні рекомендації щодо підвищення ефективності податкової реформи в Україні, які мають за мету дати змогу територіальним громадам сформувати прогресивний та раціональний бюджет. Проведене дослідження окреслює проблеми та пропонує основні шляхи наповнення місцевих бюджетів. Це стане рушійною силою та стимулом для ефективного соціально-економічного розвитку територій.

Ключові слова: фінанси територіальної громади; місцевий бюджет; бюджетна децентралізація; податки; фінансові засоби.

Вступ. Проблемою всіх країн світу є забезпечення достатніх надходжень для досягнення соціально-економічного розвитку регіонів. Її вирішення полягає в побудові ефективної системи оподаткування та чинної податкової політики держави.

Найважливішою ознакою демократичного розвитку країни $\epsilon$ наявність у ній місцевого самоврядування, здатного забезпечити ефективне функціонування територіальних громад, вирішувати питання соціально-економічного розвитку. Така здатність потребує відповідного фінансового забезпечення та дотримання принципу децентралізації влади. Згідно з чинним законодавством України держава гарантує дохідну базу місцевого самоврядування, яка має бути достатньою для забезпечення населення послугами на рівні мінімальних соціальних стандартів.

Чинна в Україні податкова система наразі не влаштовує ані бізнес, ані державу. Українська економіка страждає від величезного, порівняно із країнами з аналогічним рівнем розвитку, податкового навантаження. Основною проблемою сучасної системи оподаткування $\epsilon$ нерівномірність iï податкового тягаря: тиск перекладається на сумлінних платників та тих, хто не здатен захиститися від податківців. Натомість інші платники по- датків отримують фактичні податкові привілеї. Це робить оподаткування не просто несправедливим, а й перетворює його на засіб нечесної конкуренції, встановлення монополій, отримання адміністративної (корупційної) ренти, тощо.

Також нинішня модель бюджетних відносин в Україні характеризується надмірною централізацією податкових надходжень, асиметрією між зобов'язаннями та доходами органів місцевого самоврядування.

Забезпечення фінансової самостійності місцевих бюджетів, що передбачено оновленим Бюджетним кодексом України, у практичній площині не підкріплюється збалансованістю міжбюджетних відносин, а проголошене реформування фінансової системи залишається недостатньо ефективним. Відсутність працездатної моделі, спрямованої на вирішення проблеми перерозподілу відповідальності, компетенції, функцій i фінансових ресурсів між центральними органами влади та органами місцевого самоврядування, свідчить про нагальну потребу подальшого реформування системи державних фінансів.

Одним із напрямів підвищення рівня фінансової автономності місцевих органів влади є децентралізація, яка передбачала б законодавче врегулювання питань

\section{Інформація про авторів:}

Добош Назар Миколайович, канд. екон. наук, доцент кафедри фінансів, обліку і aналізу. Email: nazar_dobosh@ukr.net; https://orcid.org/0000-0001-6600-2111

Данилків Христина Петрівна, канд. екон. наук, асистент, кафедра фінансів, обліку і aналізу. Email: krisdanko@ukr.net; https://orcid.org/0000-0003-1283-6844

Гориславець Павло Анатолійович, канд. екон. наук, доцент, кафедра фінансів. Email: pavlo.a.horyslavets@lpnu.ua; https://orcid.org/0000-0002-1882-2104

Цитування за ДСТУ: Добош Н. М., Данилків Х. П., Гориславець П. А. Формування доходів об'єднаних територіальних громад в умовах удосконалення податкового законодавства. Науковий вісник Нлту України. Серія Економічна. 2018, т. 28, № 4. С. 4651

Citation APA: Dobosh, N. M., Danylkiv, K. P., \& Horyslavets, P. A. (2018). Income Formation of the Joint Territorial Communities in the Terms of Improvement of Tax Legislation. Scientific Bulletin of UNFU, 28(4), 46-51. https://doi.org/10.15421/40280408 
бюджетної самостійності територіальних громад з урахуванням економічних, географічних, історичних та інших критеріїв їх розвитку. Досвід унітарних європейських країн щодо організації та забезпечення процесу децентралізації свідчить про успішність такого кроку для забезпечення якісних та доступних суспільних послуг громадянам.

Тому питання оптимального розмежування податкових надходжень між бюджетами різних рівнів набувають особливої актуальності в умовах реформування бюджетного та податкового законодавства, які нібито спрямовані на бюджетну децентралізацію.

Проблеми впливу реформування податкової системи країни на формування доходів територіальних громад тією чи іншою мірою досліджували у працях багатьох українських вчених. Значного наукового поступу у цьому питанні досягли такі науковці: О. Василик, В. Дем'янишин, М. Данилишин, Т. Сфименко, О. Кириленко, В. Кравченко, А. Крисоватий, І. Ковальов, В. Кулешір, П. Мельник, І. Луніна, К. Павлюк, В. Плескач, Г. Поляк, Г. Старостенко, Л. Тарангул, І. Усков, В. Федосов та інші, дослідження яких свідчать, що податкове регулювання $\epsilon$ важливим інструментом впливу на розвиток економічної системи і соціальної сфери країни.

Однак, незважаючи на наявність великої кількості досліджень у цій сфері, практичні аспекти формування податкових надходжень місцевих бюджетів потребують подальших досліджень, що пов'язано з прийняттям змін до Бюджетного та Податкового кодексів України.

Метою дослідження $є$ поглиблення теоретико-методологічних основ та розроблення практичних рекомендацій, спрямованих на підвищення ефективності впровадження податкової реформи в Україні в контексті формування доходів територіальних громад.
Предметом дослідження є теоретичні, методичні та практичні аспекти управління доходами місцевих бюджетів України.

Об'єктом дослідження є формування доходів територіальних громад та процес управління ними.

Викладення основного матеріалу дослідження. Змістом податкового регулювання держави $є$ розроблення основних джерел наповнення бюджетів, враховуючи потреба виконання завдань, які стоять перед територіальною громадою на кожному етапі іiі розвитку. У сучасних умовах розвитку економіки, коли підвищується роль держави в регулюванні економічних процесів, особливо важливо визначити основні напрями податкової політики для забезпечення стратегічної спрямованості розвитку економіки країни та регіонів.

Зміна економічних умов господарювання створює нові проблеми стосовно підвищення ефективності податкового регулювання як у державі, так і на регіональному рівні. Метою і головним завданням податкового регулювання на місцевому рівні на найближчу перспективу є побудова сприятливих умов для розвитку реального сектору економіки, стабілізації фінансового становища підприємств на конкретній території, насамперед внаслідок зниження податкового навантаження та зміни в адмініструванні податків, що сплачуються у різні рівні бюджетів.

Розглянемо та проаналізуємо доходи зведеного, державного та місцевих бюджетів України за 2014-2016 pp. (табл. 1). Як можна бачити з таблиці, доходи місцевих бюджетів становлять в середньому 20-22 \% у зведеному бюджеті держави. Наслідком цього $є$ значна бюджетна централізація, що не сприяє вирішенню основних проблем територіальних громад в регіонах.

Таб̆л. 1. Доходи зведеного, державного та місцевих бюджетів України за 2014-2016 рр.

\begin{tabular}{|c|c|c|c|c|c|c|}
\hline \multirow{3}{*}{ Показник } & \multirow{2}{*}{\multicolumn{4}{|c|}{ Рік }} & \multicolumn{2}{|c|}{2016 р. проти 2015 р. } \\
\hline & & & & & Абсолютний & Темп \\
\hline & 2013 & 2014 & 2015 & 2016 & приріст, млрд грн & приросту, \% \\
\hline Зведений бюджет, млрд грн, зокрема: & 398,3 & 445,5 & 442,8 & 455,9 & 13,1 & 3,0 \\
\hline загальний фонд & 334,7 & 369,7 & 75,0 & 388,9 & 13,9 & 3,7 \\
\hline спеціальний фонд & 63,6 & 75,8 & 67,8 & 67,0 & $-0,8$ & $-1,2$ \\
\hline $\begin{array}{l}\text { Державний бюджет (без урахування між- } \\
\text { бюджетних трансфертів), млрд грн, зокре- } \\
\text { ма: }\end{array}$ & 311,8 & 344,7 & 337,6 & 354,8 & 17,2 & 5,1 \\
\hline частка у доходах зведеного бюджету, \% & 78,3 & 77,4 & 76,2 & 77,8 & $x$ & $\times$ \\
\hline загальний фонд & 263,3 & 288,5 & 290,1 & 308,7 & 18,6 & 6,4 \\
\hline спеціальний фонд & 48,5 & 56,2 & 47,5 & 46,1 & $-1,4$ & $-3,0$ \\
\hline $\begin{array}{l}\text { Місцеві бюджети (без урахування міжбю- } \\
\text { джетних трансфертів), млрд грн, зокрема: }\end{array}$ & 86,5 & 100,8 & 105,2 & 101,1 & $-4,1$ & $-3,9$ \\
\hline частка у доходах зведеного бюджету, \% & 21,7 & 22,6 & 23,8 & 22,2 & $x$ & $x$ \\
\hline загальний фонд & 71,4 & 81,2 & 84,9 & 80,2 & $-4,7$ & $-5,5$ \\
\hline спеціальний фонд & 15,1 & 19,6 & 20,3 & 20,9 & 0,6 & 3,0 \\
\hline
\end{tabular}

Табл. 2. Структура доходів місцевих бюджетів України за 2011-2016 рр.

\begin{tabular}{|l|c|c|c|c|c|c|}
\hline \multirow{2}{*}{ Вид доходів } & \multicolumn{5}{c|}{ Рік } \\
\cline { 2 - 7 } & 2011 & 2012 & 2013 & 2014 & 2015 & 2016 \\
\hline Податкові надходження, \% & 80,2 & 83,2 & 83,9 & 84,5 & 85,2 & 86,8 \\
\hline Податок на доходи фізичних осіб, \%, млн грн & 62,1 & 62,6 & 63,4 & 62,5 & 60,6 & 61,4 \\
\cline { 2 - 7 } & 45895,8 & 44485,3 & 51029,3 & 54065,1 & 61066,0 & 64586,0 \\
\hline Плата за землю, \%, млн грн & 9,0 & 11,8 & 11,8 & 12,4 & 12,5 & 12,2 \\
\cline { 2 - 7 } & 6681,4 & 8362,7 & 9539,9 & 10700,9 & 12802,9 & 12581,7 \\
\hline Орендна плата, млн грн & 2386,6 & 2814,9 & 3051,3 & 3236,6 & 3614,4 & 3366,1 \\
\hline Частка орендної плати уструктурі плати за землю,\% & 64,3 & 66,3 & 68,0 & 69,8 & 71,3 & 73,7 \\
\hline Місцеві податки і збори, \% млн грн & 1,1 & 1,1 & 1,0 & 2,9 & 5,4 & 7,0 \\
\cline { 2 - 7 } & 820,0 & 808,6 & 819,4 & 2549,8 & 5456,9 & 7314,1 \\
\hline Інші податкові надходження, млн грн & 8,0 & 7,7 & 7,7 & 6,7 & 6,7 & 6,2 \\
\hline Неподаткові надходження, млн грн & 10,4 & 10,9 & 10,9 & 12,4 & 12,5 & 11,5 \\
\hline Доходи від операцій з капіталом, млн грн & 6,2 & 3,7 & 3,2 & 2,1 & 1,7 & 1,3 \\
\hline Цільові фонди, млн грн & 3,2 & 2,2 & 2,0 & 1,0 & 0,6 & 0,4 \\
\hline
\end{tabular}


Дієві механізми міжбюджетного регулювання посилюють вплив централізації бюджетних коштів у державному бюджеті, тому органи місцевого самоврядування щороку втрачають фінансову самостійність. Підтвердженням цього є те, що частка дотаційних місцевих бюджетів, які мають безпосередні міжбюджетні відносини 3 державним бюджетом і питома вага міжбюджетних трансфертів у доходах місцевих бюджетів постійно зростають (Kasperovych, 2012, p. 72).

Тепер проаналізуємо структуру доходів місцевих бюджетів України впродовж 2011-2016 рр. (табл. 2).

Основним джерелом, що забезпечує мобілізацію доходів місцевих бюджетів, $є$ податкові надходження, які водночас включать загальнодержавні податки і збори (обов'язкові платежі) та місцеві податки і збори (обов'язкові платежі) (Demkiv, 2011). Упродовж 20112016 pp. у структурі доходів місцевих бюджетів збільшується частка податкових надходжень від 80,2 до 86,8 \% доходів місцевих бюджетів (без урахування міжбюджетних трансфертів). У 2016 р. їх обсяг становив 91,2 млрд грн, що на 6,2 \% більше від показника 2015 р.

Місцеві податки і збори формують незначну частку доходів місцевих бюджетів, тобто не виконують навіть фіскальної функції, тоді як у деяких країнах місцеві податки формують більшу половину бюджету усієї країни. Потреба удосконалення системи місцевого оподаткування, вирішення її основних проблем та кардинальних питань активно ініціюється зараз органами місцевого самоврядування, особливо найменш захищеними його ланками - сільськими, селищними, районними у містах радами.

Забезпечення доходами цієї ланки місцевих бюджетів остаточно досягається за допомогою методів бюджетного регулювання. Місцеві податки і збори тут не відіграють вирішальної ролі, але вони можуть її виконати за відповідної постановки питань. Сьогодні ж проблема наповнення бюджетів низового рівня доходами залишається однією із нагальних у фінансовому і соціально-економічному аспектах, і неабияку роль у цьому можуть відіграти місцеві податки і збори. Підвищення ролі місцевих податків і збільшення частки доходів за їхній рахунок $\epsilon$ головним напрямком зміцнення місцевих бюджетів, розширення їхньої фінансової автономії.

Податок на доходи фізичних осіб продовжує зберігати позицію найвагомішого за обсягом джерела дохідної частини місцевих бюджетів $-61,4$ \% від загальних надходжень місцевих бюджетів.

Збільшення обсягів надходжень від податку на доходи фізичних осіб зумовлене легалізацією виплати заробітної плати, позитивними тенденціями зростання доходів низькооплачуваних верств населення через підвищення мінімальних соціальних гарантій та зростанням заробітної плати загалом (Zaichykova, 2008, p. 23).

Основні чинники, які позитивно впливали на надходження податку на доходи фізичних осіб, такі: збільшення ставки оподаткування до 15-17 \%; підвищення мінімальної заробітної плати та відповідне зростання фонду оплати праці; тенденція зростання номінального ВВП; введення в дію з 01.01.2007 р. оподаткування доходів платників від продажу або обміну нерухомого, рухомого майна, отриманої спадщини і подарунків.

Окрім позитивів, існують й негативні тенденції в оподаткуванні доходів фізичних осіб, що відповідно зменшує рівень податкових надходжень, зокрема: зани- ження платниками оподатковуваного доходу та ухилення від сплати податку (високий рівень податкового навантаження на фонд оплати праці спричиняє неофіційні домовленості щодо розподілу заробітної плати на офіційну та неофіційну); зараховування податку на доходи фізичних осіб до відповідного місцевого бюджету за місцем реєстрації юридичної особи; зменшення бази оподаткування через зниження загального рівня доходів працюючого населення та поглиблення бідності.

Другим за обсягом джерелом надходжень доходів до місцевих бюджетів традиційно є плата за землю. Також $€$ й інші джерела наповнення місцевих бюджетів, проте їх частка $є$ дуже малою.

Включення до складу місцевих податків єдиного податку спричинило підвищення питомої ваги місцевих податків і зборів у структурі доходів місцевих бюджетів. Відтак найвагомішим серед місцевих податків і зборів став єдиний податок. Таке зростання відбулося переважно через збільшення кількості фізичних осіб та суб'єктів малого підприємництва.

Достатньо вагомим джерелом наповнення місцевих бюджетів є податки і збори, пов'язані зі забрудненням навколишнього природного середовища. Так, одним із нововведень Податкового кодексу України стало запровадження екологічного податку замість збирання за забруднення навколишнього середовища. Податок сплачується під час придбання палива для транспортних засобів.

У перспективі основним джерелом наповнення місцевих бюджетів повинен стати податок на нерухомість. Його базу розширюють внаслідок залучення в оподаткування комерційного майна. Проте порядок його нарахування та сплати не відповідає практиці розвинених країн світу, де розмір податку залежить від вартості об'єкта нерухомості, а не від житлової площі, як визначено чинним законодавством України. Тому потрібно внести відповідні поправки до Податкового кодексу. Окрім цього, викликає сумніви можливість значних надходжень для місцевих потреб від запровадження податку на нерухомість для сільської місцевості. Оскільки в умовах економічної кризи та стрімкого зубожіння селян такі ініціативи заздалегідь приречені на провал (Monitorynh, 2014). Окрім цього, органи місцевого самоврядування повинні мати право самостійно запроваджувати на своїй території власні місцеві податки та збори, враховуючи специфіку території та наявні там потенційні об'єкти оподаткування (Zakon Ukrainy, 2014). Також потрібно вдосконалити механізми співпраці та взаємодії суб'єктів підприємницької діяльності 3 податковими органами - Державною фіскальною службою України.

Найчастіше опитані підприємці, що використовують загальну систему оподаткування, скаржаться на обтяжливе та свавільне адміністрування податків. Величезні зусилля марнуються на процедури обліку та звітності, боротьбу підприємців 3 податковими органами, пошук шляхів уникнення податків тощо, а $з$ іншого боку, контролю та адміністрування.

Податкова служба є одним з головних осередків корупції. Згідно з даними нещодавнього опитування представників бізнесу, ДФС є безумовним лідером у цьому антирейтингу. Загальне невдоволення роботою податкової системи зробило нагальним питання про глибоку податкову реформу. Головною метою реформи має бу- 
ти створення передумов для економічного зростання за рахунок вивільнення підприємницького потенціалу та сприяння реалізації конкурентних переваг країни, особливо у частині використання "людського капіталу" для пришвидшеного розвитку інтелектуально-містких галузей (Radchuk, 2014).

На структурному рівні реформа має сприяти пришвидшеному оновленню економіки через пришвидшення процесів зростання нових підприємств і галузей та відмирання старих.

Зокрема, для цього така реформа покликана:

1. Зробити правила гри у сфері оподаткування рівними, прозорими, незалежними від сваволі чиновників.

2. Знизити навантаження на сумлінних платників за рахунок більш рівномірного розподілу податкового тягаря.

3. Дозволити скасувати практику встановлення планів із надходжень.

4. Зменшити сукупні витрати держави та підприємств на адміністрування та інші суспільні втрати.

5. Радикально зменшити корупцію у податковій сфері.

Разом усе зазначене, у поєднанні з планомірним скороченням неефективних державних витрат, створить умови для зниження податкового навантаження. Така реформа має складатися 3 двох компонентів. Перший докорінна зміна правил гри у взаємовідносинах держави та платників податків, що потребує змін до самих законодавчих принципів нарахування податків. Другий глибока організаційна реформа самої податкової служби, з кадровим "перезавантаженням" (Kyrylenko, 2016).

Виходячи з наведеного вище аналізу, загальний підхід до реформування податкової системи полягає у реформуванні структури податків: податку на прибуток, ПДВ, ССВ та "перезавантаженні" органів податкового адміністрування. Відповідно до викладених вище аргументів, для підприємств нефінансового сектору пропонують замінити нинішній податок на прибуток підприємств податком на розподілений прибуток 3 нижнім порогом у вигляді податку на майно. Можливо, це буде тільки нерухоме майно (Krysovatyi \& Tomniuk, 2012, p. 105).

Це має призвести до перетворення податку на прибуток на своєрідний "спрощений податок", який загалом даватиме більше надходжень за рахунок часткової компенсації скасування ССВ. Надходження від податку гарантуватиме нижній поріг у вигляді податку на майно. Іншими словами, можна говорити про запровадження повноцінного податку на майно, який буде зараховуватися при сплаті податку на розподілений прибуток. Цей підхід вже частково застосовують у чинному законодавстві: сплачений податок на комерційну нерухомість вираховується із податкових зобов'язань 3 податку на прибуток підприємств.

Скасування ССВ потребує низки супровідних інституційних заходів, таких як ліквідація Пенсійного фонду як самостійного фонду і злиття його $з$ державним бюджетом. Їх детальний розгляд теж виходить за межі цієї роботи.

3 економічного погляду, ця складова частина реформи потребує бодай часткових компенсаторів, оскільки втрату надходжень від скасування найбільшого на сьогодні збору неможливо перекрити скороченням видатків, принаймні у короткотерміновій перспективі.
Головними компенсаторами мають стати:

- удосконалення адміністрування ПДВ і радикальне зменшення зловживань;

- підвищення ПДФО до єдиної ставки у 20 \%;

- заощадження 6-8 \% поточних витрат бюджету та Пенсійного фонду за рахунок боротьби з розкраданням, інвентаризації ПФ, повної відміни субсидування підприємств, тощо;

- певне збільшення надходжень від акцизів та плати за надра;

- можливе збільшення надходжень від модифікованого податку на прибуток понад нинішній рівень.

Мета реформування ДФС України:

1. Відновлення довіри платників податків до органів контролю.

2. Добровільна сплата податків соціально відповідальним бізнесом.

3. Перетворення ДФС України у консультаційно-сервісну службу.

4. Оптимізація та автоматизація всіх організаційних процесів ДФС України.

5. Забезпечення прав та законних інтересів громадян у сфері оподаткування та митної справи, неухильного виконання Конституції України.

6. Зниження витрат на утримання апарату служби та державних підприємств, що підпорядковані службі.

7. Збільшення інвестиційної привабливості України та сприяння створенню умов для розвитку бізнесу та економіки країни, пожвавлення ділової активності.

Паралельно 3 реформуванням податкової системи держави потрібно і провести бюджетну децентралізацію, що дало б змогу отримати територіальним громадам більше фінансової незалежності для вирішення локальних економіко-соціальних завдань.

Основними напрямами такої децентралізації мають бути:

- забезпечення бюджетної незалежності та фінансової самостійності місцевих бюджетів;

- стимулювання громад до об'єднання та формування спроможних територіальних громад;

- закріплення за місцевими бюджетами стабільних джерел доходів та розширення дохідної бази місцевих бюджетів;

- децентралізація видаткових повноважень та чіткий розподіл компетенцій, сформований за принципом субсидіарності;

- надання нових видів трансфертів та посилення відповідальності профільних міністерств за реалізацію державної політики у відповідних галузях;

- визначення нового механізму бюджетного регулювання та вирівнювання (Zrostannia, 2017).

Основу фіскальної децентралізації було закладено напередодні 2015 р. внаслідок прийняття змін до Податкового та Бюджетного кодексів, що, власне, і передбачалося коаліційною угодою. Закони покликані підвищити бюджетну та фінансову самостійність місцевих бюджетів і розширити їх дохідну базу. Серед основних інструментів фіскальної децентралізації ресурсів варто відзначити: норматив податку на доходи фізичних осіб $(60,15,40,0$ \%); 10 \% податку на прибуток підприємств приватного сектора; екологічний податок (80\%); збір 3 роздрібного продажу підакцизних товарів (від 2 до $5 \%$ від реалізації); місцеві податки (нерухоме майно, в т.ч. комерційна нерухомість, плата за землю, транспортний податок); нові види трансфертів; місцеві гарантії та запозичення (спрощення процедури); вирівнювання бюджету за доходами, а не видатками та пов'язані із цим можливості участі та впливу громади на прогнозні показники бюджету (Yaresьko, 2015). 
Зміна правил гри стосовно порядку сплати ПДФО мала би змусити на місцевому рівні боротися за робочі місця, отже, і за ПДФО, що буде надходити до місцевих бюджетів. Це поліпшило б можливості для оцінювання роботи місцевої влади та підвищило б активність і вагу місцевих політиків та громад, які змушені будуть боротися за робочі місця, а відповідно, і за роботодавців (Lunina, 2010, p. 10).

Фіскальна децентралізація дала б змогу на місцевому рівні збільшити та регулювати надходження місцевих бюджетів за рахунок місцевих податків. Джерелом, яке мало б розширити базу оподаткування та генерувати доходи, мав би стати податок на майно. До його складу увійшли податок на нерухоме майно, відмінне від земельної ділянки, плата за землю та транспортний податок.

Висновки. Враховуючи наведене вище, можна стверджувати, що регіональний розвиток сьогодні потребує особливо ретельних підходів до регулювання, підвищення дієвості застосовуваних інструментів податкового регулювання, які загалом визначаються як сукупність заходів непрямого впливу на економіку, економічні та соціальні процеси за допомогою застосування таких інструментів, як зміни встановлення податкових пільг; виду податків; податкових ставок; зниження або підвищення загального рівня оподаткування; відрахувань у бюджет [3].

У разі практичного запровадження запропонованих підходів у сфері оподаткування відбудеться справжня реформа - тобто докорінна зміна відносин між платниками та державою 3 приводу нарахування та сплати податків.

Загалом збільшення надходжень за абсолютною величиною (у постійних цінах) має стати одним з позитивних наслідків реформи. Але, на відміну від інших способів досягнення такого результату, реформа має привести до нього через зростання економіки та добровільну її детінізацію.

Само по собі вирівнювання правил гри, передбачуваність платежів, зменшення оподаткування фінансових результатів та позбавлення адміністративного-корупційного тиску повинні дати поштовх зростанню. Тим більше, що податкове навантаження на тих, хто може зростати за рахунок створення нових робочих місць істотно зменшиться.

Окрім цього, податки зменшуються у тій частині, яка має високу еластичність (виведення з тіні прибутків та зарплат), натомість збільшуються ті, від яких дуже

важко, якщо взагалі можливо, втекти: ПДВ (за рахунок упорядкування адміністрування) та податки на майно.

Отже, досягти ефективного функціонування місцевого самоврядування в Україні можна за умови подальшої децентралізації владних повноважень $з$ одночасним розширенням фінансової автономії та поступової передачі фінансових ресурсів, які формуються у відповідних територіальних громадах, у повне володіння їх органів управління, що потребуватиме комплексного підходу до реформування місцевого самоврядування, яке включає конституційну, адміністративну, територіальну і бюджетну реформи.

\section{Перелік використаних джерел}

Demkiv, O. I. (2011). Vplyv finansovoi kryzy na biudzhety orhaniv mistsevoho samovriaduvannia. Finansy Ukrainy, 8, 79-85. [In Ukrainian].

Kasperovych, Yu. V. (2012). Fiskalna transmisiia ta yii naslidky na formuvannia dokhodiv biudzhetu. Ekonomika i derzhava, 3, 70-74. [In Ukrainian].

Krysovatyi, A. I., \& Tomniuk, T. L. (2012). Administruvannia podatkiv v Ukraini: orhanizatsiia ta napriamky transformatsii. Ternopil: VPTs, "Ekonomichna dumka TNEU". 212 p. [In Ukrainian].

Kyrylenko, O. P. (2016). Orhany mistsevoho samovriaduvannia povynni maty pravo samostiino vyznachaty stavky mistsevykh podatkiv i zboriv. Retrieved from: http://www.ukurier.gov.ua/uk/articles/olga-kirilenko-organi-miscevogo-samovryaduvannya-p/. [In Ukrainian].

Lunina, I. O. (2010). Formuvannia mistsevykh biudzhetiv na osnovi pryntsypu ekvivalentnosti: shliakh do efektyvnoi biudzhetnoi systemy. Finansy Ukrainy, 9, 3-12. [In Ukrainian].

Monitorynh. (2014). Shchomisiachnyi monitorynh osnovnykh indykatoriv biudzhetnoi systemy Ukrainy. In-t biudzhetu ta sotsialno-ekonomichnykh doslidzhen. Retrieved from: http://www.ibser.org.ua/news/463/. [In Ukrainian].

Radchuk, O. (2014). Chy buty v Biudzheti 2015 detsentralizatsii? Retrieved from: http:/www.slovoidilo.ua/articles/6675/2014-1230/byt-li-v-byudzhete-2015- decentralizacii.html. [In Ukrainian].

Yaresko, N. (2015). Resurs mistsevykh biudzhetiv na 2015 rik. Retrieved from: http:/www.kmu.gov.ua/control/uk/publish/article?art id $=247868006 \&$ cat $\mathrm{id}=244276429$. [In Ukrainian].

Zaichykova, V. V. (2008). Udoskonalennia biudzhetnykh protsedur v orhanakh mistsevoho samovriaduvannia. Nauk. pratsi NDFI, 1(42), 18-27. [In Ukrainian].

Zakon Ukrainy. (2014). "Pro vnesennia zmin do Biudzhetnoho kodeksu Ukrainy shchodo reformy mizhbiudzhetnykh vidnosyn" vid 28.12.2014 r., № 79-VIII. Retrieved from: http://zakon4.rada.gov.ua/laws/show/79-19. [In Ukrainian].

Zrostannia. (2017). Ukraina: Formuvannia osnovy dlia stabilnoho zrostannia: Memorandum pro ekonomichnyi rozvytok. International Bank for Reconstruction and Development, Vol. 2. The World Bank. 442 p. [In Ukrainian].

Н. М. Добош, К. П. Данылкив, П. А. Гориславец Национальный университет "Львовская политехника", г. Львов, Украина

\section{ФОРМИРОВАНИЕ ДОХОДОВ ОБЪЕДИНЕННЫХ ТЕРРИТОРИАЛЬНЫХ ОБЩИН В УСЛОВИЯХ СОВЕРШЕНСТВОВАНИЯ НАЛОГОВОГО ЗАКОНОДАТЕЛЬСТВА}

Исследовано влияние налогов и соответственно налоговой политики государства на формирование доходов объединенных территориальных общин. В условиях бюджетной децентрализации изменения бюджетного и налогового законодательства приведут к соответствующим изменениям структуры налоговых поступлений и их разграничению между бюджетами разных уровней. Комплексная децентрализация предполагает масштабный процесс, в ходе которого выделяют отдельные элементы бюджетных и не бюджетных источников финансовых ресурсов и определяют особенности их влияния на положительный результат проводимых реформ. Также проанализирована современная модель межбюджетных отношений в Украине. В проведенном исследовании установлены факторы формирования доходов местных территориальных общин и оценено влияние на их социально-экономическое развитие. Определенные возможности и угрозы проведения реформ по децентрализации не должны стать помехой для ее реализации. Поданы практические рекомендации по увеличению эффективности внедрения налоговой реформы в Украине, которые имеют целью предоставить возможность территориальным общинам сформировать прогрессивный и рациональный бюджет. Исследование определяет проблемы и предлагает основные пути 
наполнения местных бюджетов, что станет движущей силой и стимулом для эффективного социально-экономического развития территорий.

Ключевые слова: финансы территориальной общины; местный бюджет; бюджетная децентрализация; налоги; финансовые средства.

N. M. Dobosh, K. P. Danylkiv, P. A. Horyslavets Lviv Polytechnic National University, Lviv, Ukraine

\section{INCOME FORMATION OF THE JOINT TERRITORIAL COMMUNITIES IN THE TERMS OF IMPROVEMENT OF TAX LEGISLATION}

The purpose of the research is to deepen theoretical and methodological foundations and develop practical recommendations aimed at increasing the efficiency of the introduction of tax reform in Ukraine in the context of the formation of revenues of territorial communities. One of the ways to increase the level of financial autonomy of local authorities is decentralization, which would involve legislative regulation of the issues of fiscal autonomy of territorial communities taking into account economic, geographical, historical and other criteria for their development.The authors have defined the influence of taxes and, accordingly, the tax policy of the state on the formation of incomes of the joined territorial communities. In the conditions of fiscal decentralization, changes in fiscal and tax legislation will lead to corresponding changes in the structure of tax revenues and their differentiation between budgets of different levels. Comprehensive decentralization involves a large-scale process, during which separate elements of budget and nonbudget sources of financial resources are identified and the peculiarities of their influence on the positive result of the reforms are determined. The subject of the research is theoretical, methodological and practical aspects of the management of revenues of local budgets of Ukraine. The object of research is the formation of incomes of territorial communities and the process of their management. In parallel with the reform of the tax system of the state, budget decentralization is necessary as well, which would allow territorial communities to gain more financial independence for solving local economic and social problems. The main areas of such decentralization should be as follows: ensuring budgetary autonomy and financial autonomy of local budgets; encouraging communities to unite and form able territorial communities; consolidation of stable sources of income from local budgets and expansion of the revenue base of local budgets; decentralization of spending powers and a clear division of competences, formed on the principle of subsidiarity; the provision of new types of transfers and strengthening the responsibility of profile ministries for the implementation of state policy in the relevant sectors; definition of a new mechanism for budgetary regulation and equalization.

Keywords: territorial community finances; local budget; budget decentralization; taxes; financial instruments. 